\title{
FISSION-TRACK AGES OF THE METALLOGENIC EPOCH OF THE IKUNO-AKENOBE PROVINCE IN JAPAN
}

\author{
Susumu Nishimura \\ Institute of Earth Science, Kyoto University, Kyoto, Japan
}

\begin{abstract}
The igneous rock specimens taken from Ikuno-Akenobe province in Japan were dated by the fission-track technique. Ages of pre-ore dikes, ranging from 72 to $65 \mathrm{my}$, are younger than ages of Ariga granite and Yakuno metamophic rocks in this province, which are $\mathbf{7 5}$ and $115 \mathrm{my}$, respectively. Being obvious from the ages of post-ore dikes, ranging from 55 to $51 \mathrm{my}$, none of the post-ore dikes in this province is younger than the Miocene time.
\end{abstract}

\section{INTRODUGTION}

Polymetallic vein-type deposits of tin, tungsten, copper, zinc, lead, silver and gold are found at Akenobe and Ikuno. These are among the best-known of Japanese deposits and have been cited as type examples of a xenothermal deposits. The ore-deposits at Akenobe, Nakase and Ikuno mines are quite similar in the assemblage of vein-forming minerals but differ in their host rocks. The host rocks at the Akenobe and Nakase are Permo-Carboniferous sedimentary rocks and Triassic rocks of the Yakuno mafic complex, while the host rocks at the Ikuno deposits are Creataceous rhyolitic pyroclastic rocks of the Ikuno Group. The ages of granitic rocks, which are found very close to these deposits, are not younger than host rocks. A number of dikes, basaltic and rhyolitic in composition, have intruded befor and after the mineralization.

The ages of these dikes have been obtained by Ishihara and Shibata using KAr method (1972). For the re-examination of metallogenic epoch of this province, the rock specimens have been dating collected.

\section{Analytical Procedure}

Zircons were separated with an isodynamic separator and heavy liquid after crushing, sieving and washing of the rock samples. Zircon is sutiable for the application of fission-track dating, because of the high uranium impurities and its high temperature stability.

The method depends on the spontaneous fission of ${ }^{238} \mathrm{U}$ atoms in mineral, taking place at a constant rate and leaving fissiontracks. Once formed, the fission tracks disappear if the material is heated above a critical temperature. The fission track age, $\mathrm{T}$ yr, can be represented by the following equation (Fleisher and Price, 1964).

$$
T=\frac{1}{\lambda} \ln \left(1+\frac{\lambda}{\lambda_{f}} \frac{\rho_{s}}{\rho_{i}} \frac{\phi \sigma}{\eta}\right)
$$

where $\rho_{s}$ is the fossil fission track density $\left(\mathrm{cm}^{-2}\right), \rho_{i}$ is the induced track density by bombardment with the thermal neutrons $\left(\mathrm{cm}^{-2}\right), \lambda$ is the total decay constant for uranium $\left(\mathrm{yr}^{-1}\right), \lambda_{f}$ is the fission decay constant for ${ }^{238 U}$ (we used $6.85 \times 10^{-17}$ 
Table 1 Fission-track ages of Ikuno-Akenobe province

\begin{tabular}{|c|c|c|c|c|}
\hline Sample & $\begin{array}{l}\text { Spontaneous } \\
\text { fission-track } \\
\text { density }\left(\mathrm{cm}^{-2}\right)\end{array}$ & $\begin{array}{l}\text { Induced } \\
\text { fission-track } \\
\text { density }\left(\mathrm{cm}^{-2}\right)\end{array}$ & $\begin{array}{l}\text { Thermal } \\
\text { neutron } \\
\text { dose }\left(\mathrm{cm}^{-2}\right)\end{array}$ & $\begin{array}{l}\text { Fission-track } \\
\text { age (my) }\end{array}$ \\
\hline \multicolumn{5}{|l|}{ Ikuno } \\
\hline Andesite dike, post-ore & $6.3 \times 10^{6}$ & $8.2 \times 10^{6}$ & $1.1 \times 10^{15}$ & 52 \\
\hline Rhyolite dike, pre-ore & $8.5 \times 10^{6}$ & $7.8 \times 10^{6}$ & $1.1 \times 10^{15}$ & 70 \\
\hline \multicolumn{5}{|l|}{ Arigg } \\
\hline Granite & $9.6 \times 10^{6}$ & $8.0 \times 10^{6}$ & $1.1 \times 10^{15}$ & 75 \\
\hline \multicolumn{5}{|l|}{ Fudo-no Taki, Haga } \\
\hline Yakuno metamorphic rock & $1.3 \times 10^{7}$ & $7.5 \times 10^{6}$ & $1.1 \times 10^{15}$ & 115 \\
\hline \multicolumn{5}{|l|}{ Nakase } \\
\hline Quartz porphyry & $7.9 \times 10^{6}$ & $7.8 \times 10^{6}$ & $1.05 \times 10^{15}$ & 65 \\
\hline Quartz diorite & $1.0 \times 10^{7}$ & $8.9 \times 10^{6}$ & $1.05 \times 10^{15}$ & 72 \\
\hline \multicolumn{5}{|l|}{ Akenobe } \\
\hline Felsite dike, post-ore & $6.7 \times 10^{6}$ & $8.5 \times 10^{6}$ & $1.05 \times 10^{15}$ & 51 \\
\hline Felsite dike, post-ore & $8.9 \times 10^{6}$ & $9.2 \times 10^{6}$ & $0.88 \times 10^{15}$ & 52 \\
\hline Pophyritic andesite & $8.5 \times 10^{6}$ & $8.8 \times 10^{6}$ & $0.88 \times 10^{15}$ & 52 \\
\hline Andesite & $8.0 \times 10^{6}$ & $7.8 \times 10^{6}$ & $0.88 \times 10^{15}$ & 55 \\
\hline
\end{tabular}

Table 2 The ages of minerals and rocks in the metallogenic province Name of ore

deposits Rocks Age Reference

Post-ore

Ikuno

Akenobe

Akenobe

Akenobe

Akenobe

Akenobe

Akenobe

Pre-ore

Ikuno

I kuno

Nakase

Nakase

Miyazu

Ariga

Ohtani.

Ohtani

Ohtani

Yakuno

Andesite dike
Felsite dike
Felsite dike
Felsite dike
Felsite dike
Porphyritic
andesite dike
Andesite dike

Felsite dike

Felsite dike

Quartz porphyry

Quartz diorite

Granite

Granite

Granodiorite

Muscovite, alter envelope

Muscovite, vein

Metamorphic rock
93.0

This work

90.0

91.4

115

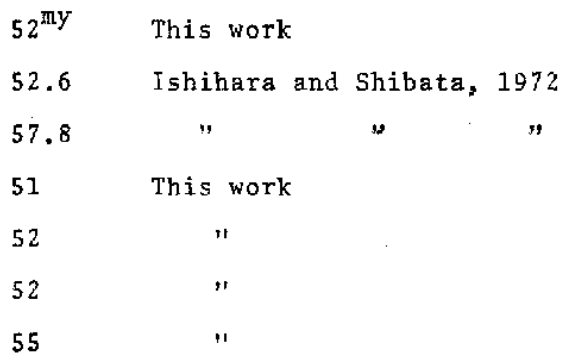


$\left.\mathrm{yr}^{-1}\right)$; Nishimiura, 1975), $\sigma$ is the thermal neutron cross section for fission ${ }^{235} \mathrm{U}\left(\mathrm{cm}^{-2}\right)$, $\phi$ is the thermal neutron dose $\left(\mathrm{cm}^{-2}\right)$, and $\eta$ is the isotope ratio ${ }^{235} \mathrm{U} /{ }^{288} \mathrm{U}$. If $\mathrm{T}$ were smaller than $10^{-9} \mathrm{yr}$, equation (1) can be written

$$
T=6.12 \times 10^{-8} \phi \frac{\rho_{s}}{\rho_{i}}
$$

Zircon required two hours at $180^{\circ} \mathrm{C}$ in 1:1 55\% $\mathrm{HF}$ and Conc. $\mathrm{H}_{2} \mathrm{SO}_{4}$ using stainless capsul and teflon inner capsul.

\section{ANALYZED SPEcimens AND Results}

Localities of the analyzed specimens and results are listed in Table 1.

Ikuno: The pre-ore dikes are rhyolite, andesite and basalt. The fission-track age of rhyolite dikes was obtained as 70 my (Table 1).

The andesite and sandstone like liparite dikes are found as post-ore dikes. The age of andesite dike was also obtained as $52 \mathrm{my}$.

Nakase: The rock specimens of pre-ore dikes were collected from Nakase mine for fission-track dating and obtained as 65 and $72 \mathrm{my}$.

Akenobe: At the Akenobe mine, the postore felsite dikes were dated as $\mathbf{5 1}$ and $\mathbf{5 2}$ my, and surrounding andesite were also obtained as 52 and 55 my.

The specimens from the host rocks of these mines were also collected from Ariga granite and Yakuno metamorphic rocks and obtained as 75 and $115 \mathrm{my}$, respectively.

\section{Discussion}

The dates of these rocks were obtained by Kawano and Ueda (1966), Ishihara and
Shibata (1972) and Shibata and Ishihara (1974) as shown in Table 2.

From these data, the age of tangusten, tin and molybdenum deposits in this province were ranging from 70 to $90 \mathrm{my}$ with pultonic rocks, that of polymetallic vein type deposits were 70 to 55 my with pultonic and subvolcanic activities and then gold and silver ore are deposited with subvolcanism.

\section{AGKNOWLEDGMENTS}

Grateful thanks are due to the staffs of all mines visited for the guidance during our field studies and also Profs. $T$. Nakamura and T. Kasama of University of Osaka City and Prof. K. Wadatsumi of Himeji Technical Colledge for helpful comments on this studies. I wish also to express our appreciation to Prof. S. Iwata and the members of the Research Reactor Institute of Kyoto University for the use of their facilities in neutron irradiation.

\section{REFENCES}

Fleischer, R.L. and Price, P.B. (1964), Techniques for geological dating of minerals by chemical etching of fission fragment tracks, Geochim. Cosmochim. Acta, 28, 1705-1714.

Ishihara, S. and Shibata, K. (1972) Re-examination of the Metallogenic epoch of the IrunoAkenobe province, in Japan, Mining Geol., 22, 67-75.

Kawano, Y. and Ueda, Y. (1966), K-Ar dating on the igneous rocks in Japan (1) - Granitic rocks in Southwestern Japan, Jap. Assoc. Min. Petr. Econ. Geol. Jour., 56, 191-211.

Nishimura, S. (1975), On the value of the decay constant for spontaneous fission of uranium-238, Mem. Fac. Sci., Kyoto Univ., Ser. Geol. Min., 41, 15-19.

Shibata, K. and Ishihara, S. (1974), K-Ar ages of the major Tungsten and Molybdenum deposits in Japan, Econ. Geol., 69, 1207-1214. 
生野・明延鉱床の鉌化時代のフィッション・トラックによる年代決定

西村進*

フィッション・トラック法莫生野・明延鉱森の火成岩飞ついて適用した。その結果，鉱化前の岩脈について

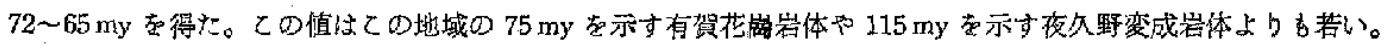

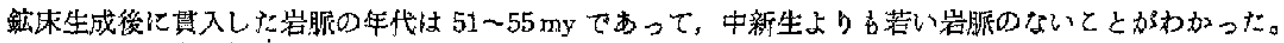

